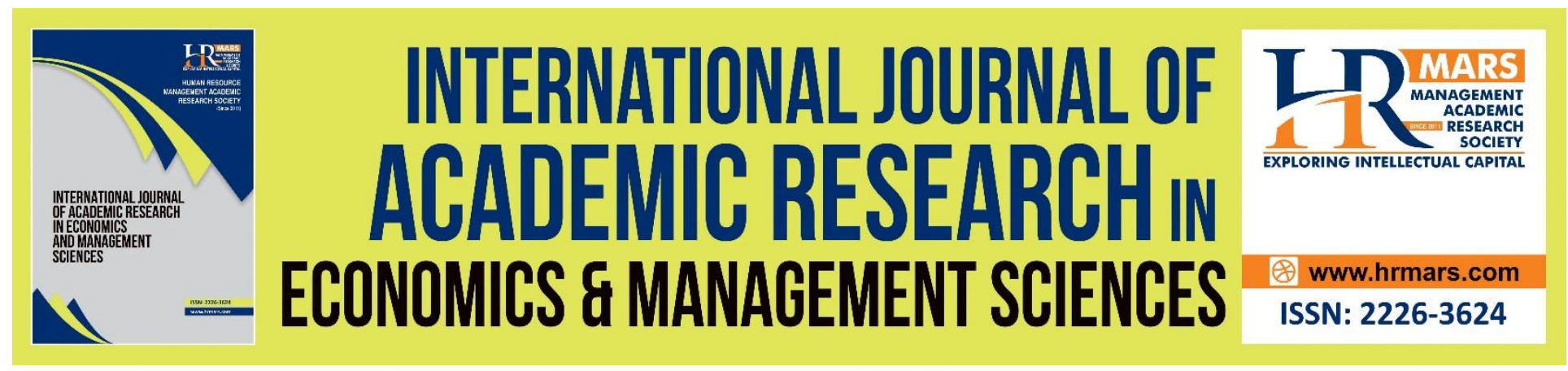

\title{
Impact of Economic Factors towards Exchange Rate in Malaysia
}

Suhana Mohamed, Meezatulakma Abdullah, Mohd Khairul Ariff Noh, Mohamad Azwan Md Isa, Siti Salwa Hassan, Wan Muhd Faez Wan Ibrahim, and Ferri Nasrul

To Link this Article: http://dx.doi.org/10.6007/IJAREMS/v10-i1/9213

DOI:10.6007/IJAREMS/v10-i1/9213

Received: 26 January 2021, Revised: 24 February 2021, Accepted: 15 March 2021

Published Online: 30 March 2021

In-Text Citation: (Mohamed et al., 2021)

To Cite this Article: Mohamed, S., Abdullah, M., Noh, M. K. A., Isa, M. A. M., Hassan, S. S., Ibrahim, W. M. F. W., \& Nasrul, F. (2021). Impact of Economic Factors towards Exchange Rate in Malaysia. International Journal of Academic Research in Economics and Managment and Sciences, 10(1), 81-91.

Copyright: (C) 2021 The Author(s)

Published by Human Resource Management Academic Research Society (www.hrmars.com)

This article is published under the Creative Commons Attribution (CC BY 4.0) license. Anyone may reproduce, distribute, translate and create derivative works of this article (for both commercial and non-commercial purposes), subject to full attribution to the original publication and authors. The full terms of this license may be seen at: http://creativecommons.org/licences/by/4.0/legalcode

Vol. 10, No. 1, 2021, Pg. 81 - 91

http://hrmars.com/index.php/pages/detail/IJAREMS

JOURNAL HOMEPAGE

Full Terms \& Conditions of access and use can be found at http://hrmars.com/index.php/pages/detail/publication-ethics 


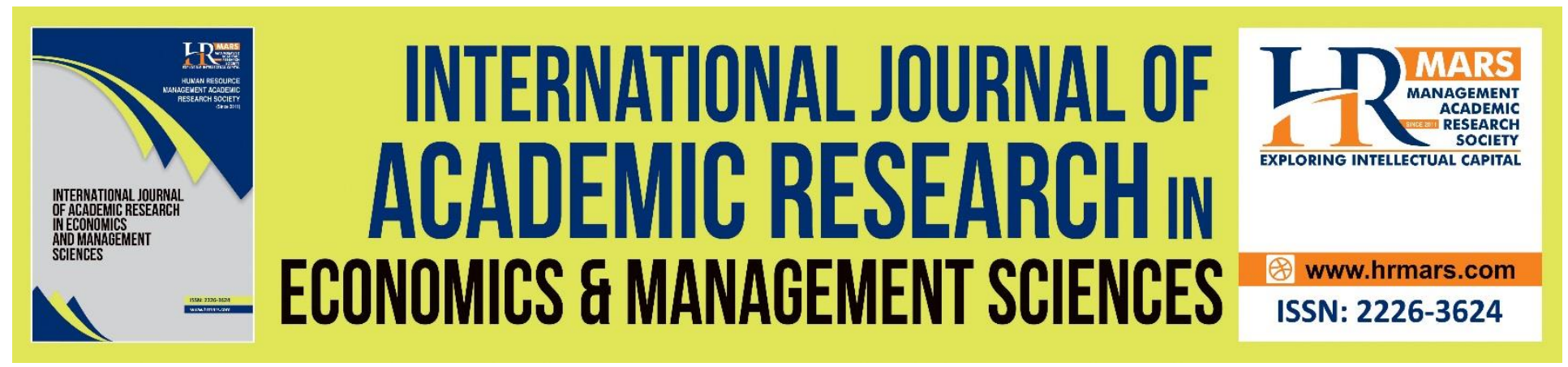

\title{
Impact of Economic Factors towards Exchange Rate in Malaysia
}

\author{
Suhana Mohamed ${ }^{1}$, Meezatulakma Abdullah ${ }^{1}$, Mohd Khairul Ariff \\ Noh$^{2}$, Mohamad Azwan Md Isa², Siti Salwa Hassan², Wan Muhd \\ Faez Wan Ibrahim ${ }^{3}$, and Ferri Nasrul ${ }^{2}$ \\ ${ }^{1}$ Faculty of Business and Management, Universiti Teknologi MARA, Johor Branch, Pasir Gudang \\ Campus, Johor Malaysia, ${ }^{2}$ Faculty of Business and Management, Universiti Teknologi MARA, \\ Johor Branch, Segamat Campus, Johor Malaysia, ${ }^{3}$ Faculty of Business and Management, \\ Universiti Teknologi MARA, Sarawak Branch, Samarahan Campus, Sarawak Malaysia \\ Email: suhan291@uitm.edu.my, ariff890@uitm.edu.my, salwahassan@uitm.edu.my
}

\begin{abstract}
As the exchange rate is currently floating negatively in Malaysia, there is a need to investigate the impact of economic factors on Malaysia's exchange rate volatility. In this study, the annual time series data for foreign exchange rates, gross domestic product and unemployment rates obtained from the World Development Indicators (WDI) source. The data for inflation rates sourced from the Department Statistic of Malaysia website. The 120 observations data tested from 1989 to 2018 using Eviews software. First, the data analyzed based on the descriptive statistics measure the mean, minimum, maximum, kurtosis, and skewness of the data or variables. The Augmented Dickey-Fuller (ADF) and Phillips-Perron (P.P.) used to test the data stationarity. The correlation test is performed to investigate any correlation between the variables. Lastly, the multiple regression analysis examines the impacts and significance of the relationship between the variables. The findings demonstrate that there is a strong significant relationship between gross domestic product and exchange rate. However, unemployment and inflation show an insignificant relationship with exchange rate volatility. There is a strong significant relationship between gross domestic product, inflation with the exchange rate. However, unemployment shows an insignificant relationship with the exchange rate. This study indicated economic factors that increase gross domestic product and inflation, significantly impacting the exchange rate. To maintain Malaysia's exchange rate stability, Malaysia needs to look into their monetary policy closely.
\end{abstract}

Keywords: Impact, Economics Factors, Exchange Rates, Malaysia.

\section{Introduction}

For most countries in the twentieth century, the exchange rate stabilized by government activity instead of financial institutions. Before World War I, the value of the world's primary monetary 
forms was settled in terms of gold, whereas for an era after World War II, most monetary forms were settled in terms of the U.S. dollar.

For example, an interbank exchange rate of 4.19 Ringgit Malaysia to the United States dollar means that RM4.19 will be exchanged for each US\$ 1 or that US\$1 will be exchanged for each RM4.19. Since 2014, US\$1 to R.M. has been RM3.4335 and kept increasing until now. The highest exchange rate was in December 2016 with RM4.4895. This exchange rate is still in the floating mode because of a few economic factors.

The current issues on Malaysia currency-vulnerabilities of Ringgit Malaysia started in 2014. The Ringgit started to depreciate in late 2014. On December 1 2014, the Ringgit had its most substantial two-day depreciation since the 1997-1998 Asian financial crisis, from 3.3465 per U.S. Dollar, falling 2.4 percent to 3.4300 to the U.S. Dollar at closing. In June 2015, it was reported that the Ringgit had dropped for four consecutive weeks in the year's longest losing stretch so far. The primary cause for the drop in Ringgit's value due to oil's lower value. Oil is one of Malaysia's main exports, and the currency is affected because of the declining price of Brent crude oil. As the oil supply exceeded demand, it reduced the oil prices because of the high production of oil in the U.S. Bank Negara did not peg the MYR and exercise institute capital control for Malaysia. This is because the exchange rate regime can help the country adopt Ringgit's value changes.

The exchange rate influences the country's daily consumer spending and affects the economy aggregate demand through its impact on export and import costs, and arrangement producers may exploit this association. Malaysia is a developing country, so the foreign exchange rate is essential to large importers and exporters.

\section{Research Background}

The exchange rate system is often associated with economic uncertainties. This was as happened during the Asian Financial crisis, which led to Malaysia's GDP decreasing from US\$100.8 billion in 1996 to US\$72.2 billion in 1998. Among the factors that caused the crisis to affect the economy in Malaysia was a speculative attack in the foreign exchange market, and the situation caused the exchange rate to change from RM2.42 for 1 U.S. dollar to decline by nearly 50 percent, and hit a high of RM4.88 to the U.S. dollar on January 71998 (Ariff and Yanti, 1999). Also, the composite Index $(\mathrm{Cl})$ of the Kuala Lumpur Stock Exchange (KLSE), which was the region's thirdlargest stock exchange after Tokyo and Hong Kong, fell right to 262.7 points on September 1, 1997, from 1,077.3 points in June 1997 (Yanti, 2002).

Besides speculation in the foreign exchange market, other key sources of the Ringgit's devaluation are lower oil values. As Malaysia relies on oil as a major export, any price change will affect the Ringgit's value. Exchange rates are significant not only to a country's economy but also on daily consumer spending, export and import costs. Therefore, the below study carried out to identify several determinants that lead to foreign exchange rates. Identified determinants are gross domestic products, unemployment and inflation.

\section{Foreign Exchange}

There have been numerous studies found on foreign exchange rates. Majeed (2018) discovered that foreign exchange rates were also used as an index to determine a country's currency competitiveness. The researcher also summarized that the country's currency was more 
competitive between the two had such relationships as if the index value fell. The focus of the study based on an empirical relationship between exchange rates and macroeconomic variables, i.e. gross domestic product (GDP), unemployment (U.N.) and current balance accounts (C.B.) in Pakistan using annual data from 1995 to 2016.

Patel (2014) also stated that foreign conversion rates used to sell currencies and pave the investment way. It will enable the currency exchange established to monitor the movement of foreign exchange values based on worldwide events and the economic assessment of each country involved.

Parveen, Khan, and Ismail (2018) tested various factors affecting the diversity of Pakistan's exchange rates. My and Sayim (2016) also conducted studies on the effects of macroeconomic factors on foreign exchange rates between the United States and four emerging countries: India, Mexico, Brazil, and China from 2005 to 2014. Both studies found that foreign exchange rates also determined by the country's government and not according to market forces.

\section{Foreign Exchange and Gross Domestic Products}

The gross domestic product (GDP) defined as a measure of all finished goods and services produced and offered by a country for a certain period, i.e. one year. GDP considers variables such as total government spending, money spent by businesses, private consumption and national exports. Several studies completed shows the association between foreign exchange and gross domestic product.

Ramasamy and Abar (2015) examined the critical macroeconomic variable relationships and their influence on exchange rates and found that gross domestic product can influence exchange rates. In contrast, Parveen et al. (2018) have concluded that economic growth was a critical second variable that brought more variations in exchange rates as occurred in Pakistan. Also, Mirchandani (2013) also found a positive relationship between foreign exchange and gross domestic product. Exchange and income rates have weak and indirect relationships in the short term but not in the long run. My and Sayim (2016) supported it, which found a positive relationship between gross domestic product and foreign exchange rate.

Mahmood et al. (2011) showed that the volatility of positive exchange rates affected Pakistan's gross domestic product in the annual panel data for the period 1975 to 2015 . Another study conducted by Diego (2016) found macroeconomic factors (GDP) influenced the exchange rate towards the U.S. Dollar with other currencies. The result based on the macroeconomic data on foreign exchange rates between the United States and four large emerging countries from 2005 to 2014. Other studies found no relationship between GDP and foreign exchange by Majeed (2018) and Harberger (2003). Both agreed that an increase in GDP would not affect the foreign exchange rate.

\section{Foreign Exchange and Unemployment}

According to the World Bank's definition, unemployment refers to the labour forces that do not have any work but are available to find jobs. The association between foreign exchange and unemployment studied. The first study found a one-way relationship that occurred between foreign exchange and unemployment. In conclusion, when unemployment increases, foreign exchange will also increase (Choi, 2018). 
Similarly, Majeed (2018) found significant effects between unemployment and foreign exchange, indicating that unemployment was significantly positive at $1 \%$. Meanwhile, in a study, Ran and Zhou (2012) found that a $1 \%$ increase in U.S. unemployment rates caused, on average, a $0.53 \%$ increase in Hong Kong unemployment under the relevant exchange rate system. The findings meant that unemployment positively correlates with a foreign exchange between the U.S. Dollar and the Hong Kong currency.

A study in China by Fu and Lin (2012) identified changes to China's exchange rate regime during 2001-2009. The study also examined the effects of China's interest rate difference (IRD) and an unemployment rate at exchange rates using Cointegrating Testing and Vector Error Correction. The result is the same as previous researchers, whose higher unemployment would lead to Yuan depreciation. The research supported by Feldmann (2011) based on data in 17 industrialized countries from 1982 to 2003 and controlling various factors, and researchers found that higher exchange rate volatility increased the unemployment rate.

\section{Foreign Exchange and Inflation}

The following variable that could potentially affect the exchange rate is inflation. Inflation generally means general price increases and the fall in the value of money purchases. Based on several research findings, foreign exchange and inflation have a positive relationship. A study by Patel et al. (2014) argued that if India's inflation rate were lower than other countries by comparison, then Indian exports would rise, and there would be increased demand for Rupee to buy Indian goods. Therefore, lower inflation rates tend to see an increase in the value of any country's currency.

For Venkatesan and Ponnamma (2017), in a macroeconomic factor study affecting key exchange rates against Rupee and identifying the relationship between exchange rates and macroeconomic variables, inflation negatively impacted and, therefore, higher inflation affected foreign exchange rates. The study supported by Parveen et al. (2018) found that the exchange rate in Pakistan would be affected because inflation negatively impacted foreign exchange rates. When inflation increases, the value of the currency will decline.

Mirchandani (2013) studied the relationship between inflation and exchange rates stated that inflation rates and medium exchange rates were related, and statistical analysis showed an indirect relationship between the inflation rate and the exchange rate. Similar findings also expressed by Khan (2016) in Pakistan and found a positive relationship between inflation and foreign exchange. The researchers noted that exports, interests and inflation had significant relationships, while import and current accounts were insignificant. The contrary findings by Maurya (2017), which assumed a variety of macroeconomic variables that determine the exchange rate found that inflation differences had no significant impact on exchange rates.

\section{Research Methodology}

This section provides details on the data and methodology used in this study. The annual time series data for foreign exchange rates, gross domestic product and unemployment rates attained from the World Development Indicators (WDI) source. Meanwhile, the data for inflation rates traced from the Department Statistic of Malaysia website. In this study, the data tested spans from 1989 to 2018, consisting of 120 observations for all variables. The data collected is analyzed 
INTERNATIONAL JOURNAL OF ACADEMIC RESEARCH ECONOMICS AND MANAGEMENT SCIENCES Vol. 10, No. 1, 2021, E-ISSN: 2226-3624 @ 2021 HRMARS

and interpreted using Eviews software. The following table summarizes the data used in this study.

Table 1: Summary of Data

\begin{tabular}{|l|l|l|l|}
\hline Variables & Abbreviation & Proxy & Remark \\
\hline Foreign Exchange Rate & EXC & $\begin{array}{l}\text { Real useful exchange } \\
\text { rate index (2010=100) }\end{array}$ & Dependent variable \\
\hline Gross Domestic Product & GDP & $\begin{array}{l}\text { GDP per capita } \\
\text { (constant 2010 US\$) }\end{array}$ & Independent variable \\
\hline Unemployment Rate & U.N. & $\begin{array}{l}\text { Total \% of the total } \\
\text { labour force (national } \\
\text { estimate) }\end{array}$ & Independent variable \\
\hline Inflation Rate & I.R. & $\begin{array}{l}\text { Consumer Price Index } \\
\text { (CPI) }\end{array}$ & Independent variable \\
\hline
\end{tabular}

The following hypotheses statements developed for this study are stated as follow:

HO: $\quad$ There is no significant relationship between independent variables (gross domestic product, unemployment and inflation) and foreign exchange in Malaysia.

H1: $\quad$ There is a significant relationship between independent variables (gross domestic product, unemployment and inflation) and foreign exchange in Malaysia.

First, we analyze the data based on the descriptive statistics that measure the central tendency and dispersion. The measurements include the mean, minimum, maximum, kurtosis, and skewness of the data or variables. Next, we perform the unit root test to examine the stationarity of data. If the $p$-value is less than the 5 percent significance level, we conclude that the variable's data is stationary. The Augmented Dickey-Fuller (ADF) and Phillips-Perron (P.P.) used to test the data stationarity.

Then, we conduct the correlation test to investigate the correlational movement between the dependent and independent variables. Besides, we also check if there is any correlation between the respective independent variables. The correlation results range between the values of -1.0 to +1.0 that assess the weak or strong variation in one variable as another variable varies.

Lastly, we conduct the multiple regression analysis that examines the impacts and significance of the relationship between the independent variables and dependent variables. The regression coefficients and $p$-values show the significance of each independent variable in predicting the dependent variable. The regression results, among others, will be analyzed based on the $t$-test, $f$-test and Durbin Watson statistics.

The regression model for this study is stated as follows:

$E X C i=b_{0}+b_{1} G D P_{i}+b_{2} U N_{i}+b_{3} I R_{i}+\varepsilon_{i}$

EXC, GDP, U.N. and IF stands for the dependent and independent variables, as summarized in the above table. The $\beta_{0}$ and $\varepsilon_{i}$ represent the constant value and error term or residual, respectively. Meanwhile, the $\beta_{1}, \beta_{2}$ and $\beta_{3}$ refer to the beta coefficient of each independent variable. The beta coefficient measures the impact, either positive or negative, on the dependent variable. 
INTERNATIONAL JOURNAL OF ACADEMIC RESEARCH ECONOMICS AND MANAGEMENT SCIENCES

Vol. 10, No. 1, 2021, E-ISSN: 2226-3624 ㄷ 2021 HRMARS

\section{Findings and Discussion}

The study listed three independent variables; gross domestic product, unemployment and inflation and a dependent variable: the foreign exchange rate.

\section{Descriptive Analysis}

Table 2: Descriptive Statistics for Factors Affecting Foreign Exchange in Malaysia

\begin{tabular}{|l|l|l|l|l|}
\hline Items & EXC & GDP & UN & INF \\
\hline Mean & 103.6482 & 7873.574 & 3.431467 & 87.03342 \\
\hline Median & 98.74201 & 7547.587 & 3.380000 & 84.63952 \\
\hline Maximum & 124.8827 & 12109.49 & 5.730000 & 120.6632 \\
\hline Minimum & 85.12324 & 4280.953 & 2.450000 & 55.36441 \\
\hline Std. Dev. & 12.63438 & 2162.996 & 0.593090 & 19.37634 \\
\hline Skewness & 0.549132 & 0.254300 & 1.942028 & 0.083936 \\
\hline Kurtosis & 1.904975 & 2.188008 & 9.014584 & 1.931820 \\
\hline Jarque-Bera & 3.006580 & 1.147505 & 64.07640 & 1.461487 \\
\hline Probability & 0.222397 & 0.563407 & 0.000000 & 0.481551 \\
\hline Sum & 3109.446 & 236207.2 & 102.9440 & 2611.003 \\
\hline Sum Sq. Dev. & 4629.197 & $1.36 \mathrm{E}+08$ & 10.20091 & 10887.83 \\
\hline
\end{tabular}

Table 2 reported that GDP was the highest mean score, and it showed that it has the most influential factor in the exchange rate in Malaysia. The lowest mean score is 3.43 in U.N., which indicated that this variable was the least factor that influences the foreign exchange rate in Malaysia. INF is the second important factor influencing the foreign exchange rate as the mean score is 87.03 .

\section{Unit Root Test}

Table 3: Result of Unit Root Test - Augmented Dickey-Fuller (ADF)

\begin{tabular}{|l|l|l|}
\hline Variable & Level & $\mathbf{1}^{\text {st }}$ Different \\
\hline EXC & 0.3746 & $0.0053^{*}$ \\
\hline GDP & 0.8982 & $0.0016^{*}$ \\
\hline UN & $0.0025^{*}$ & $0.0044^{*}$ \\
\hline INF & 0.6741 & $0.0002^{*}$ \\
\hline
\end{tabular}

As illustrated in Table 3, all the variables had values less than 5 percent at a first different level. Thus, the results indicated that all variables were significant to the foreign exchange rate in Malaysia. 


\section{Normality and Pearson Analysis}

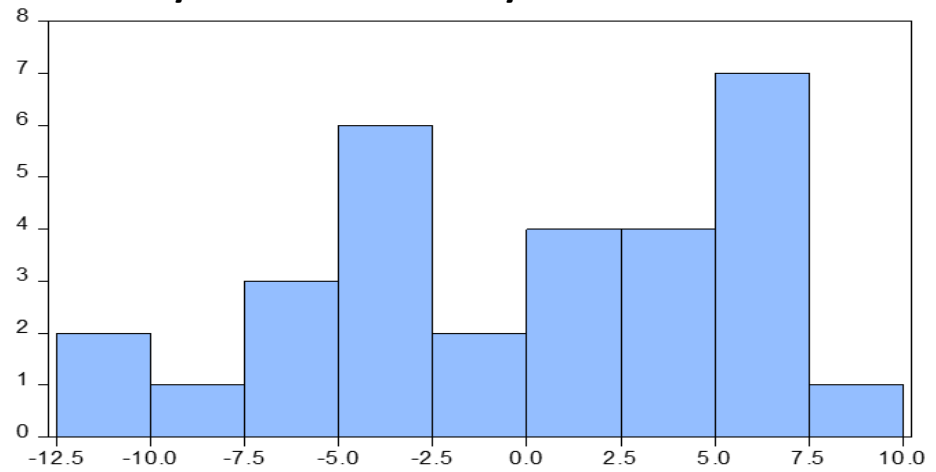

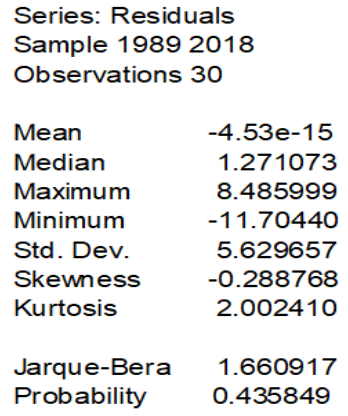

Figure 1: Normality analysis

As shown in Figure 1, the p-value of Jarque-Bera was 1.660917, which indicated that the error term normally distributed.

Table 4: Pearson Correlation Analysis

\begin{tabular}{|l|l|l|l|l|}
\hline Correlation Probability & EXC & GDP & UN & INF \\
\hline EXC & 1.000000 & & & \\
\hline & ---- & & & \\
\hline GDP & -0.797392 & 1.000000 & & \\
\hline & 0.0000 & ---- & & \\
\hline UN & 0.292269 & -0.470550 & 1.000000 & \\
\hline & 0.1171 & 0.0087 & ---- & \\
\hline INF & -0.846868 & 0.989979 & -0.438383 & 1.000000 \\
\hline & 0.0000 & 0.0000 & 0.0154 & ----- \\
\hline
\end{tabular}

Table 4 showed the correlation matrix of the independent variables studied. The foreign exchange rate correlates with only two independent variables that were gross domestic product and inflation. However, unemployment has no linear relationship with the dependent variable.

\section{Multiple Regression Analysis}

A series of regression analysis was executed based on the basic ordinary least squares (OLS), and the results are summarized in Table 5 using the econometric equation as stated below:

$\mathrm{UNi}=173.0658+0.011951(\mathrm{GDPi})-0.110286(\mathrm{UNi})-1.874397(\mathrm{INFi})+\varepsilon$

Table 5: Result of Multiple Regression

\begin{tabular}{|l|l|l|l|l|l|}
\hline Variable & Coefficient & t-Statistics & Prob & Items & Value \\
\hline EXC & 173.0658 & 15.15819 & 0.0000 & R-squared & 0.801456 \\
\hline GDP & 0.011951 & 3.166132 & 0.0039 & Adjusted R-squared & 0.778547 \\
\hline UN & -0.110286 & -0.050991 & 0.9597 & F-statistic & 34.98451 \\
\hline INF & -1.874397 & -4.531191 & 0.0001 & uProb(F-statistic) & 0.000000 \\
\hline
\end{tabular}

Based on the result from Table 5, the coefficient of each independent variable discloses important information. The unemployment rate and inflation rate showed negative impacts on the foreign exchange rate in Malaysia. Results showed that the $p$-value of unemployment was 
0.9597, which strongly indicated no significant and negative relationship between unemployment and foreign exchange. While the $p$-value of inflation was 0.0001 , which is smaller than 0.05 level of significance explained to reject the null hypothesis. The result strongly explained that there was a significant and negative relationship between inflation and foreign exchange.

Furthermore, the result of R-square indicated $80.15 \%$ of the variance. As shown in Table 4 , the F-tests indicate that all the variables explain the impacts of economic factors on Malaysia's foreign exchange rate. Besides that, the models' explanatory power, as shown by the adjusted Rsquare value, was high, $77.85 \%$.

\section{Conclusion and Recommendation}

The conclusion and recommendation were discussed in the following sections.

\section{Conclusion}

This paper attempted to examine the impact of economic factors on Foreign Exchange rate volatility in Malaysia from 1989 to 2018 based on annual time series data. Selected variables are chosen, namely Gross Domestic Product (GDP), Inflation (INF) and Unemployment (U.N.), as an independent variable. Various methods employed in examining the relationship between exchange rate and independent variables.

\section{Research Objective 1: To examine the relationship between Gross Domestic Product and the} Foreign Exchange rate in Malaysia

The discussion above shows sufficient evidence to conclude the significant relationship between Gross Domestic Product and Foreign Exchange rate at a 5 percent level of confidence. As the GDP coefficient shows a negative value, it can be concluded that there is a significant and negative relationship between GDP and the foreign exchange rate. It is consistent with Mirchandani, A. (2013), Ramasamy, R., \& Abar, S. K. (2015) and My, N. Q., \& Sayim, M. (2016). However, it contradicts the findings by Majeed, M. (2018).

\section{Research Objective 2: To examine the relationship between Inflation and the Foreign Exchange} rate in Malaysia

The finding shows a significant and negative relationship between inflation and the Foreign Exchange rate at a 5 percent level of confidence. It is consistent with Mirchandani, A. (2013), Venkatesan et al., (2017) and Parveen et al., (2018). However, it is in contrast with the findings by Khan, I. (2016).

Research Objective 3: To examine the relationship between Unemployment and Foreign Exchange rate in Malaysia

Based on the findings, results indicated no significant relationship between unemployment and the Foreign Exchange rate. The coefficient correlation indicated a negative relationship between the two variables. This result is consistent with Ramasamy \& Abar (2015) findings and Fu \& Lin (2012). 


\section{Recommendation}

\section{Use More Variable}

Future researchers suggested using more independent variables such as exchange rate, interest rate and real wages. If more independent variables used, then the result is robust and accurate and more additional information or facts while investigating the variables' relationship. The inclusion of these variables would provide the researcher with a broader-based understanding.

\section{Different Type of Data Structure}

The researchers recommended trying different data structures such as monthly, monthly, or weekly for future study. The reason is that different independent variables might have different sensitivity on a different frequency. However, there is always a challenge while collecting secondary data. Many researchers are always facing a problem and limitation while collecting data. Thus, the researcher might need to consider this limitation and overcome it when collecting secondary data.

\section{Geographical Nature}

Different countries may have different outcome in findings. Using different countries suggests that future researchers exploring different norms and policies in one country might affect the study results. Therefore, it will add to the current literature and provide updates to the academicians and researchers of related fields.

\section{Corresponding Author}

Mohd Khairul Ariff Noh.

Department of Finance, Faculty of Business and Management, Universiti Teknologi MARA, Johor Branch, Segamat Campus, Jalan Universiti, 85009 Segamat, Johor, Malaysia.

Email: ariff890@uitm.edu.my

\section{References}

Ariff, M., \& Yanti, S. (1999). The Malaysian Financial Crisis: Economic Impact and Recovery Prospects. The Developing Economies, XXXVII-4, 417-438. Retrieved from https://www.ide.go.jp/library/English/Publish/Periodicals/De/pdf/99_04_03.pdf

Choi, Y., \& Choi, E. K. (2018). Unemployment and optimal exchange rate in an open economy. Economic Modelling, 69, 82-90. Retrieved from https://doi.org/10.1016/j.econmod.2017.09.009

Doukas, J., \& Lifland, S. (2008). Exchange Rates and the Role of the Trade Balance Account. Managerial Finance, 20(5), 67-78. https://doi.org/10.1108/eb018476

Feldmann, H. (2011). The unemployment effect of exchange rate volatility in industrial countries. Economics Letters, 111(3), 268-271. https://doi.org/10.1016/j.econlet.2011.01.003

Fu, T., \& Lin, M. (2012). Interest rate, unemployment rate China's and China's exchange rate regime. https://doi.org/10.1108/17468801211209947

Greenaway, R., Mark, N. C., Sul, D., \& Wu, J. L. (2012). Exchange Rates as Exchange Rate Common Factors.

Khan, I. (2016). Factors Affecting Exchange Rate: A case of Pakistan. (75209). 
Khan, R. S. A. (2014). Raja Sher Ali Khan. 16(6), 115-121.

Mahmood, I., Ehsanullah, M., \& Ahmed, H. (2011). Exchange Rate Volatility \& Macroeconomic Variables in Pakistan (C) Society for Business and Management Dynamics (C) Society for Business and Management Dynamics. 1(2), 11-22.

Majeed, M. (2018). Impact of GDP, unemployment and the current balance on the exchange rate: a study from. 6(June), 37-46.

Maurya, S. (2017). Factors affecting Exchange Rate and its Impact on the Economy of India. (January 2017). https://doi.org/10.5958/2249-7307.2017.00148.7

Mirchandani, A. (2013). Analysis of Macroeconomic Determinants of Exchange Rate Volatility in India. 3(1), 172-179.

My, N. Q., \& Sayim, M. (2016). The Impact of Economic Factors on the Foreign Exchange Rates between the USA and Four Big Emerging. 3(1). https://doi.org/10.5296/ifb.v3i1.9108

Parveen, S., Khan, A. Q., \& Ismail, M. (2018). Analysis of the Factors Affecting Exchange Rate Variability in Pakistan analysis of the factors affecting the exchange rate. (January 2012).

Patel, P. P. J., Patel, N. J., \& Patel, A. R. (2014). Factors affecting Currency Exchange Rate, Economical Formulas and Prediction Models. 3(3), 53-56.

Ramasamy, R., \& Abar, S. K. (2015). Influence of Macroeconomic Variables on Exchange Rates. 3(2), 276-281. https://doi.org/10.7763/JOEBM.2015.V3.194

Ran, J., \& Zhou, Y. (2012). Transmitted unemployment under the linked exchange rate system: Evidence from Hong Kong. Economics Letters, 117(1), 131-133. https://doi.org/10.1016/j.econlet.2012.04.096

Venkatesan, T., \& Ponnamma, M. S. (2017). An Analysis of Macroeconomic Factors Affecting Foreign Exchange Rate. 21-30. https://doi.org/10.18311/sdmimd/2017/15716.

Yanti, S. A. B. (2002). Migrant labour in Malaysia: Impact and implication of the Asian financial crisis. EADN Regional Project on the Social Impact of the Asian Financial Crisis.Retrieved from http://www.eadn.org/Migrant\%20Labour\%20in\%20Malaysia\% 20Impact\%20and\%20Implications\%20of\%20the.pdf 